\title{
PENINGKATAN AKTIVITAS BELAJAR AKUNTANSI MELALUI \\ PENERAPAN NHT DENGAN MEDIA SOFTWARE JIGSAW PUZZLE
}

\author{
Dicky Pradana \\ Prodi Pendidikan Akuntansi Universitas Negeri Yogyakarta \\ dicky_imo@yahoo.com
}

\begin{abstract}
Abstrak
Penelitian ini adalah Penelitian Tindakan Kelas yang bertujuan untuk meningkatkan Aktivitas Belajar Akuntansi siswa kelas X Akuntansi 3 SMK Negeri 7 Yogyakarta tahun ajaran 2013/2014 melalui Model Pembelajaran Kooperatif Tipe Numbered Heads Together (NHT) dengan Media Software Jigsaw Puzzle. Penelitian ini dilaksanakan dengan dua siklus dalam dua pertemuan. Pengumpulan data penelitian ini dilakukan dengan observasi dan angket. Analisis data yang dilakukan adalah analisis data deskriptif kuantitatif yang menunjukkan penilaian aktivitas belajar siswa. Berdasarkan data hasil penelitian Aktivitas Belajar Siswa meningkat yang ditunjukkan dengan adanya peningkatan persentase skor observasi siklus I sebesar 77,23\% dan siklus II sebesar 90,07\%, hal ini berarti terdapat peningkatan sebesar $12,84 \%$ (Absolut) dan 16,63\% (Relatif). Selain itu berdasarkan angket yang didistribusikan kepada siswa juga terjadi peningkatan persentase Aktivitas Belajar Akuntansi siswa sebesar 10,77\% (absolut) dan 13,83\% (relatif) dimana persentase pada siklus I sebesar $77,87 \%$ meningkat menjadi $88,64 \%$ pada siklus II.
\end{abstract}

Kata kunci : Model Pembelajaran Kooperatif, Numbered Heads Together (NHT), Software Jigsaw Puzzle, Aktivitas Belajar

\begin{abstract}
This research is a Classroom Action Research aimed to improve students' Accounting Learning Activity of Grade X Accounting 3 at SMK Negeri 7 Yogyakarta academic year of 2013/2014, through the Implementation of Cooperative Learning Model Type Numbered Heads Together (NHT) using Jigsaw Puzzle Software Media. This research was conducted in two cycles within two meetings. The data collection technique is by the observation and questionnaire, while the data analysis technique is descriptive quantitative data analysis that showed the assessment of Students' Learning Activity. Based on the research result, the Students' Learning Activity are improved, it can be seen from the improvement in the percentage score of observation result that reached $77,23 \%$ on the first cycle and increased to $90,07 \%$ on the second cycle, it means that there are the improvement of 12,84\% (Absolute) and 16,63\% (Relative). Besides, from the questionnaire result that have been distributed to the students, there is also an improvement of Students' Accounting Learning Activity at the amount of 10,77\% (absolute) and 13,83\% (relative) where the percentage score of the first cycle is $77,87 \%$ increased to $88,64 \%$ on the second cycle.
\end{abstract}

Keywords : Cooperative Learning Model, Numbered heads Together (NHT), Jigsaw Puzzle Software, Learning Activity 


\section{PENDAHULUAN}

Suatu negara dianggap maju dalam masa globalisasi, apabila memiliki kualitas pendidikan yang baik, menjadi salah satu pilar pembangunan bagi suatu negara untuk dapat bersaing dikancah dunia. Pendidikan merupakan salah satu faktor penunjang yang sangat penting bagi perkembangan peradaban manusia dalam suatu bangsa. Bangsa yang mempunyai peradaban maju adalah bangsa yang mempunyai sumber daya manusia yang berkualitas. Tentu harus dilakukan suatu usaha untuk meningkatkan kualitas pendidikan. Salah satunya dengan melakukan evaluasi kualitas sistem pendidikan secara menyeluruh. Menurut Dwi Siswoyo (2008: 18), secara teknis pendidikan adalah proses di mana masyarakat melalui lembagalembaga pendidikan (sekolah, perguruan tinggi, atau lembaga-lembaga lain) dengan sengaja mentransformasikan warisan budayanya, yaitu pengetahuan, nilai-nilai, dan keterampilan-keterampilan dari generasi ke generasi.

Pendidikan dalam proses belajar mengajar dapat diwujudkan dengan adanya interaksi antara siswa dan guru. Siswa sebagai pihak yang belajar sedangkan guru adalah pihak yang mengajar, dengan kata lain, siswa menjadi subjek pokok dalam belajar. Interaksi yang ditimbulkan dalam belajar mengajar pada prinsipnya memiliki sebuah tujuan pembelajaran. Upaya yang dapat dilakukan yaitu dengan menggunakan langkahlangkah prosedural sebagai pedoman sehingga memunculkan adanya aktivitas siswa yang berlangsung pada kurun waktu tertentu, sedangkan guru berperan sebagai pembimbing agar proses pembelajaran tersebut berlangsung secara efektif.

Menurut Oemar Hamalik (2005: 172), belajar tidaklah cukup hanya dengan mendengar dan melihat tetapi harus dengan melakukan aktivitas yang lain, diantaranya: membaca, bertanya, menjawab, berpendapat, mengerjakan tugas, menggambar, mengkomunikasikan, presentasi, diskusi, menyimpulkan, dan memanfaatkan peralatan. Ngalim Purwanto (2007: 102-106) juga mengungkapkan bahwa pembelajaran yang efektif dipengaruhi oleh dua faktor, yaitu faktor internal dan eksternal. Faktor internal adalah faktor yang berkaitan dengan diri peserta didik, meliputi: kemampuan, minat, motivasi, dan keaktifan belajar, sedangkan faktor eksternal adalah faktor dari luar diri peserta didik, antara lain: model pembelajaran, media pembelajaran, sarana dan prasarana. Proses pembelajaran yang efektif akan membuat peserta didik aktif selama proses pembelajaran. Hal ini sesuai dengan yang disebutkan Martinis Yamin 
(2007: 81-82) bahwa belajar aktif ditandai bukan hanya melalui aktivitas peserta didik secara fisik, namun juga aktivitas mental.

$$
\text { Dapat disimpulkan bahwa }
$$
perbaikan pendidikan dapat ditempuh melalui aktivitas peserta didik dengan menggunakan model pembelajaran yang digunakan secara tepat oleh guru. Penggunaan model pembelajaran yang tepat dapat meningkatkan efisiensi dan efektifitas dalam proses belajar mengajar. Kenyataan di lapangan banyak dijumpai gaya mengajar yang kurang bervariasi dan belum memanfaatkan kemampuan siswa secara maksimal. Guru kurang memperhatikan bahwa penggunaan model belajar yang kurang tepat dapat menyebabkan kurangnya keaktifan siswa dalam proses belajar mengajar, sehingga tujuan dari pembelajaran tidak tercapai secara optimal.

Berdasarkan observasi awal yang dilakukan pada awal Januari 2014 di kelas X Akuntansi 3 SMK Negeri 7 Yogyakarta yang terdiri dari 32 siswa, ditemukan beberapa masalah, yaitu peserta didik kurang aktif selama proses pembelajaran meskipun guru telah memancing mereka untuk bertanya, menjawab, menyanggah pernyataan atau berdiskusi. Peserta didik lebih banyak diam saat pembelajaran berlangsung, bahkan saat menemui kesulitan mereka lebih memilih diam dan tidak bertanya kepada guru. Saat pembelajaran berlangsung, guru sering kali harus menunggu peserta didik untuk bertanya tentang materi pelajaran yang belum dipahami atau menjawab pertanyaan yang diberikan oleh guru. Bahkan guru harus memanggil nama peserta didik untuk menjawab atau bertanya, namun peserta didik tersebut hanya diam atau menjawab dengan raguragu. Apabila guru mengajukan pertanyaan lisan, hanya sekitar 3 - 5 siswa atau 9\% $15 \%$ yang berani menjawab pertanyaan atau mengemukakan pendapatnya secara pasti, dan hanya terdapat $10-12$ siswa atau sekitar 30\% - 36\% yang aktif di kelas selama proses pembelajaran.

Belum maksimalnya aktivitas belajar peserta didik tersebut disebabkan oleh beberapa faktor, antara lain kondisi psikologis peserta didik, cara guru mengajar dan media pembelajaran yang digunakan guru di kelas. Selain itu, dalam proses pembelajaran guru belum menggunakan media pembelajaran yang bervariasi sehingga peserta didik hanya membaca buku atau modul sebagai sumber belajar. Model pembelajaran yang diterapkan oleh guru masih menggunakan metode ceramah kemudian tanya jawab, hal tersebut membuat peserta didik bosan dan tidak aktif selama proses 
pembelajaran. Sehingga guru harus dapat menerapkan model pembelajaran yang tepat untuk meningkatkan aktivitas siswa.

Faktanya, pembelajaran Akuntansi membutuhkan keaktifan peserta didik untuk mengukur tingkat pemahaman mereka dalam menyerap materi. Apabila peserta didik tidak aktif selama proses pembelajaran, (misalnya bertanya mengenai pemecahan latihan soal yang dihadapi), guru tidak dapat mengetahui materi mana yang belum dipahami peserta didik. Guru dapat menerapkan berbagai model pembelajaran untuk meningkatkan aktivitas peserta didik, salah satunya dengan model pembelajaran kooperatif dimana peserta didik akan bekerja sama dalam suatu kelompok sehingga kemampuan kerja sama juga terasah.

Model Pembelajaran kooperatif memposisikan peserta didik sebagai subjek yang berinteraksi dengan peserta didik lain dan banyak melakukan aktivitas belajar dalam kelompoknya. Peserta didik bekerja dalam kelompok sekaligus bertanggung jawab atas kesuksesan kelompoknya. Setiap anggota dalam kelompok saling memiliki ketergantungan positif sehingga memicu setiap anggota kelompok tersebut untuk selalu berperan aktif demi memberikan hasil yang terbaik.

Terdapat banyak tipe dalam pembelajaran kooperatif yang dapat digunakan dalam proses pembelajaran, Salah satunya adalah Numbered Heads Together (NHT). Pembelajaran kooperatif tipe ini merupakan tipe pembelajaran yang dirancang untuk mempengaruhi pola interaksi, memiliki tujuan untuk meningkatkan keaktifan dan penguasaan pemahaman materi oleh peserta didik. Pembelajaran dengan menggunakan model tersebut melibatkan siswa dalam melihat kembali bahan yang tercakup dalam suatu pelajaran dan memeriksa pemahaman siswa mengenai isi pelajaran tersebut. Dengan begitu peserta didik akan lebih banyak beraktivitas karena peserta didik saling bekerja sama dalam kelompok untuk memahami materi yang diberikan oleh guru. Model ini menempatkan peserta didik sebagai pusat dalam pembelajaran, dimana peserta didik diberi ruang untuk aktif selama proses pembelajaran berlangsung. Model ini menuntut guru agar dapat membimbing peserta didik dalam belajar secara berkelompok. Menurut Slavin (2009: 102) pembelajaran konstruktivisme dalam pengajaran menerapkan model pembelajaran kooperatif secara ekstensif, atas dasar teori bahwa peserta didik akan lebih mudah menemukan dan memahami konsepkonsep yang sulit apabila mereka saling mendiskusikan konsep tersebut.

Di era globalisasi ini, masyarakat 
dituntut untuk up to date terhadap teknologi yang berkembang khususnya di dunia pendidikan. Saat ini telah banyak diciptakan software atau piranti lunak yang dapat digunakan untuk mendukung berlangsungnya proses pembelajaran, salah satunya yaitu Software Jigsaw Puzzle. Perangkat lunak ini sangat cocok untuk digunakan sebagai media pembelajaran di SMK, mengingat usia anak SMK yang masih senang bermain dan menyukai halhal yang baru khususnya teknologi terkini. Puzzle merupakan bentuk media yang menantang daya kreatifitas dan ingatan siswa lebih mendalam dikarenakan munculnya aktivitas untuk senantiasa mencoba memecahkan masalah, terus berusaha dan membuat suasana menyenangkan. Tantangan dalam permainan ini akan memberikan efek ketagihan untuk selalu mencoba memecahkan teka-teki yang ada hingga berhasil. Selain itu, dengan diterapkannya Software Jigsaw Puzzle sebagai media belajar suasana pembelajaran akan menjadi lebih menarik, perhatian siswa lebih terpusat dan aktivitas akan lebih teraktualisasi dalam diri siswa di setiap kelompok.

Mata pelajaran yang diajarkan dalam penelitian ini adalah Kompetensi Kejuruan Akuntansi (KKA) dimana memiliki Standar Kompetensi (SK) yang merupakan pernyataan minimal atau memadai yang mencakup pengetahuan, keterampilan, sikap, nilai yang direfleksikan dalam kebiasaan bertindak, berpikir setelah siswa menyelesaikan suatu aspek atau sub aspek mata pelajaran dan Kompetensi Dasar (KD) yang merupakan kemampuan minimal dalam mata pelajaran yang harus dimiliki, direfleksikan dalam kebiasaan berpikir, bertindak yang harus ditempuh oleh siswa kelas X Akuntansi 3. Salah satunya yaitu pada Standar Kompetensi Memproses Entri Jurnal Perusahaan Dagang dan Kompetensi Dasar Melakukan Pencatatan Transaksi dalam Jurnal.

Depdiknas menyebutkan bahwa akuntansi merupakan bahan kajian mengenai suatu sistem untuk menghasilkan informasi berkenaan dengan transaksi keuangan. Informasi tersebut dapat digunakan dalam rangka pengambilan keputusan dan tanggungjawab di bidang keuangan baik oleh pelaku ekonomi swasta (akuntansi perusahaan), pemerintah (akuntansi pemerintah), ataupun organisasi masyarakat lainnya (akuntansi publik). Oleh karena itu, kompetensi dasar melakukan pencatatan transaksi dalam jurnal pada perusahaan dagang menjadi suatu hal penting yang harus ditempuh dan dikuasai oleh siswa SMK khususnya siswa 
kelas $\mathrm{X}$ Akuntansi 3 SMK Negeri 7 Yogyakarta guna menjadi seorang yang memiliki kemampuan, sebagai akuntan yang handal di masyarakat.

Sesuai dengan analisis situasi yang telah disebutkan, peneliti melakukan penelitian dengan judul "Implementasi Model Pembelajaran Kooperatif Tipe Numbered Heads Together (NHT) dengan Media Software Jigsaw Puzzle untuk Meningkatkan Aktivitas Belajar Akuntansi Siswa Kelas X Akuntansi 3 SMK Negeri 7 Yogyakarta Tahun Ajaran 2013/2014”.

\section{METODE}

\section{Desain Penelitian}

Jenis penelitian ini merupakan penelitian tindakan kelas (classroom action research). Penelitian ini akan dilakukan dengan menggunakan dua siklus. Prosedur Penelitian Tindakan Kelas menggunakan model yang dikembangkan Kemmis dan Taggart.

\section{Subjek dan Objek Penelitian}

Subjek dalam penelitian ini adalah siswa kelas X Akuntansi 3 SMK Negeri 7 Yogyakarta tahun ajaran 2013/2014 yang terdiri dari 32 siswa, Sedangkan yang menjadi objek penelitian adalah Aktivitas Belajar Akuntansi Siswa Kelas X Akuntansi 3 Kompetensi Keahlian Akuntansi di SMK Negeri 7 Yogyakarta.

\section{Prosedur Penelitian}

Penelitian ini dilakukan dalam dua siklus, akan tetapi apabila hasil yang diperoleh belum memenuhi indikator keberhasilan yang telah ditetapkan maka dilanjutkan untuk siklus selanjutnya. Prosedur penelitian setiap siklus terdiri dari empat tahapan, yaitu tahap perencanaan, pelaksanaan, pengamatan dan refleksi.

Pada siklus I tahap perencanaan terdiri dari kegiatan merancang media modul, menyusun RPP, membuat soal latihan. Tahap pelaksanaan tindakan merupakan kegiatan melaksanakan RPP yang telah dirancang di kelas dengan menggunakan model pembelajaran kooperatif tipe Numbered Heads Together dengan Media Software Jigsaw Puzzle. Tahap yang ketiga yaitu tahap pengamatan yang berlangsung bersamaan dengan pelaksanaan tindakan. Pada tahap ini observer mengamati aktivitas belajar akuntansi siswa selama pembelajaran. Tahap terakhir adalah reflesi yang bertujuan untuk mengkaji secara menyeluruh tindakan yang telah dilakukan berdasarkan data yang telah terkumpul, kemudian dilakukan evaluasi guna menyempurnakan tindakan berikutnya.

Prosedur pada siklus II secara garis besar sama dengan prosedur penelitian pada siklus I. Perencanaan siklus II 
merupakan hasil refleksi pelaksanaan siklus I. Siklus II merupakan perbaikan dari pelaksanaan siklus I, sehingga kekurangan pada siklus I tidak terulang pada siklus II.

\section{Teknik Pengumpulan Data dan Instrumen}

Teknik pengumpulan data pada penelitian ini menggunakan adalah observasi dan angket. Pengumpulan data yang berhubungan dengan peningkatan Aktivitas Belajar Akuntansi dengan merapkan model pembelajaran Tipe Numbered Heads Together (NHT) dengan Media Software Jigsaw Puzzle dilakukan dengan observasi partisipatif. Observer mengamati secara langsung jalannya pembelajaran untuk mendapatkan data Aktivitas Belajar Akuntansi. Observer menagamati jalannya pembelajaran dengan berpedoman pada pedoman observasi Aktivitas Belajar Akuntansi yang berisi indikator-indikator Aktivitas Belajar Akuntansi.

Angket dalam penelitian ini digunakan untuk memperoleh data Aktivitas Belajar Akuntansi dari siswa terhadap penerapan model pembelajaran Tipe Numbered Heads Together (NHT) dengan Media Software Jigsaw Puzzle. Angket atau kuesioner. Dengan digunakannya angket pada penelitian ini, maka data Aktivitas Belajar Akuntansi dapat diperoleh dari subjek penelitian secara langsung, dalam hal ini adalah siswa.

\section{Teknik Analisis Data}

Teknik analisis yang digunakan dalam penelitian ini adalah analisis data kuantitatif dan kualitatif. Teknik analisis data kuantitatif digunakan untuk mengetahui skor Aktivitas Belajar Akuntansi siswa. Langkah-langkah menganalisis data secara kuantitatif adalah sebagai berikut:

a. Menentukan kriteria pemberian skor terhadap masing-masing indikator.

b. Menjumlahkan skor untuk setiap kegiatan aktivitas belajar.

c. Menghitung skor aktivitas belajar dengan rumus,

$\%=\frac{\text { Skor Aktivitas Belajar Akuntansi }}{\text { Skor Maksimum }} \times 100 \%$

(Sugiyono, $2007:$ 144)

Teknik analisis data kualitatif terdiri dari tiga langkah. Pertama, mereduksi data maksudnya merangkum, memilih hal-hal yang pokok, memfokuskan pada hal yang penting dan membuang yang tidak perlu. Kedua, menyajikan data merupakan penyusunan informasi secara sistematik dari hasil 
reduksi data, dimulai dari perencanaan, pelaksanaan tindakan observasi dan refleksi sehingga akan mudah dipahami. Tahap terakhir adalah verifikasi atau penarikan kesimpulan.

\section{Indikator Keberhasilan}

Kriteria keberhasilan tindakan adalah apabila setelah penerapan Model Pembelajaran Tipe Numbered Heads Together (NHT) dengan Media Software Jigsaw Puzzle, terjadi peningkatan Aktivitas Belajar Akuntansi. Pembelajaran dapat dikatakan berhasil dan berkualitas jika seluruhnya atau sebagian besar $75 \%$ siswa terlibat secara aktif baik fisik maupun mental (Mulyasa, 2008: 101).

\section{HASIL PENELITIAN DAN PEMBAHASAN}

Berdasarkan hasil observasi siklus I, diketahui bahwa terdapat tiga indikator aktivitas belajar yang belum mencapai kriteria ketuntasan minimal yang ditentukan sebesar $75 \%$ yaitu membaca materi pelajaran akuntansi $(70,31 \%)$, mencatat materi pelajaran akuntansi $(71,88 \%)$ dan menanggapi pendapat siswa lain dalam diskusi $(72,66 \%)$. Pada siklus II diketahui bahwa terdapat 7 indikator aktivitas belajar telah mencapai kriteria ketuntasan minimal yang ditentukan sebesar $75 \%$.
Tabel 1. Peningkatan Persentase Aktivitas Belajar Akuntansi Siswa Siklus I - Siklus II

\begin{tabular}{|c|c|c|c|c|c|}
\hline \multirow[b]{2}{*}{ Po. } & \multirow[b]{2}{*}{ Indikator } & \multicolumn{2}{|c|}{ Skor } & \multicolumn{2}{|c|}{ Peningkatan } \\
\hline & & $\begin{array}{c}\text { Siklus } \\
\text { I }\end{array}$ & $\begin{array}{c}\text { Siklas } \\
\text { II }\end{array}$ & Absolat & Relatif \\
\hline 1. & $\begin{array}{l}\text { Membaca matei } \\
\text { pelajaran } \\
\text { Alountansi }\end{array}$ & $70,31 \%$ & $87,50 \%$ & $17,19 \%$ & $24,45 \%$ \\
\hline 2. & $\begin{array}{l}\text { Mencatar mateni } \\
\text { pelajaran } \\
\text { Akuntansi }\end{array}$ & $71,88 \%$ & $89,84 \%$ & $17,96 \%$ & $24,99 \%$ \\
\hline 3. & $\begin{array}{l}\text { Mengeriakan latihan soal } \\
\text { yang diberkan guru }\end{array}$ & $82,81 \%$ & $90,63 \%$ & $7,82 \%$ & $9,44 \%$ \\
\hline 4. & $\begin{array}{l}\text { Melakukan dishosi } \\
\text { kelompok }\end{array}$ & $84,38 \%$ & $93,75 \%$ & $9,37 \%$ & $11,10 \%$ \\
\hline 5. & $\begin{array}{l}\text { Menjawab pertanyaan } \\
\text { dari guru maupun teman } \\
\text { selama diskusi }\end{array}$ & $82,03 \%$ & $92,97 \%$ & $10,94 \%$ & $13,34 \%$ \\
\hline 6. & $\begin{array}{l}\text { Menanggapi pendapat } \\
\text { siswa lain selams diskus }\end{array}$ & $72,66 \%$ & $87,50 \%$ & $14,84 \%$ & $20,42 \%$ \\
\hline 7. & $\begin{array}{l}\text { Mengeriakan ksis yang } \\
\text { diberikan guru secara } \\
\text { mandin }\end{array}$ & $76,56 \%$ & $88,28 \%$ & $11,72 \%$ & $15,31 \%$ \\
\hline & Skor rata-rata & $77,23 \%$ & $90,07 \%$ & $12,84 \%$ & $16,63 \%$ \\
\hline
\end{tabular}

Selain peningkatan persentase Aktivitas Belajar Akuntansi Siswa dari siklus I - siklus II, diketahui juga data sebagai berikut:

Tabel 2. Peningkatan Jumlah Siswa yang Aktif

\begin{tabular}{|c|c|l|c|c|c|}
\hline No. & Rentang Skor & Kriteria & $\begin{array}{c}\text { Siklus } \\
\text { I }\end{array}$ & $\begin{array}{c}\text { Sikfus } \\
\text { II }\end{array}$ & Peningkatan \\
\hline 1 & $80-100$ & Sangat Aktif & 9 & 32 & 23 \\
\hline 2 & $66-79$ & Aktif & 20 & 0 & 0 \\
\hline 3 & $56-65$ & Cukup Aktif & 3 & 0 & 0 \\
\hline 4 & $40-55$ & Kurang Aktif & 0 & 0 & 0 \\
\hline 5 & $30-39$ & Tidak Aktif & 0 & 0 & 0 \\
\hline
\end{tabular}

Terjadi peningkatan aktivitas belajar akuntansi siswa dimana pada siklus I terdapat 9 siswa yang tergolong sangat aktif dan 20 siswa yang tergolong aktif, 
pada siklus II seluruh siswa yang berjumlah 32 tergolong sangat aktif.

Tabel 3. Perbandingan Data Angket Aktivitas Belajar Akuntansi Siklus I dan Siklus II

\begin{tabular}{|c|c|c|c|c|c|}
\hline \multirow[b]{2}{*}{$\mathrm{Ne}$} & \multirow[b]{2}{*}{ Indikator } & \multicolumn{2}{|c|}{ Skor } & \multicolumn{2}{|c|}{ Peningkatan } \\
\hline & & $\frac{\text { Siklos }}{\mathrm{I}}$ & $\frac{\text { Sokhs }}{\text { II }}$ & Absolat & Rehatif \\
\hline 1 & $\begin{array}{l}\text { Menhaca mateil } \\
\text { pelaiarn } \\
\text { Ahntans }\end{array}$ & $\begin{array}{c}74,48 \\
\%\end{array}$ & $\begin{array}{c}90,10 \\
5 / 2\end{array}$ & $15,62 \%$ & $2097 \%$ \\
\hline 2 & $\begin{array}{l}\text { Mencatat mateli } \\
\text { pelajarn } \\
\text { Aluntang }\end{array}$ & $\begin{array}{c}73,83 \\
\%\end{array}$ & $\begin{array}{c}89,06 \\
1 / 2\end{array}$ & $1523 \%$ & $20,63 \%$ \\
\hline 3. & $\begin{array}{l}\text { Mengerukm latihan soal } \\
\text { rang diterkn gur }\end{array}$ & $\begin{array}{c}82,42 \\
\%\end{array}$ & 88,28 & $5,86 \%$ & $7,11^{1} / \mathrm{s}$ \\
\hline 4 & $\begin{array}{l}\text { Melakikan disingi } \\
\text { kelumpol }\end{array}$ & $\begin{array}{c}82,62 \\
\%\end{array}$ & $\begin{array}{c}85,74 \\
16\end{array}$ & $3,12 \%$ & 3,784 \\
\hline 5. & $\begin{array}{l}\text { Menjawab petanvan } \\
\text { dari guru wapun teman } \\
\text { sclana dishoi }\end{array}$ & $\begin{array}{c}78,91 \\
\%\end{array}$ & $\begin{array}{c}88,67 \\
\%\end{array}$ & $9,76 \%$ & $1237 \%$ \\
\hline 6 & $\begin{array}{l}\text { Menanggagi pendapar: } \\
\text { פiswa lain solama dishrs }\end{array}$ & $\begin{array}{c}73,96 \\
\%\end{array}$ & $\begin{array}{c}88,02 \\
3\end{array}$ & $14,06 \%$ & $19,01 \%$ \\
\hline 2 & $\begin{array}{l}\text { Mengerilun knis yang } \\
\text { dherikan guru secara } \\
\text { mandini }\end{array}$ & $\begin{array}{c}78,91 \\
\%\end{array}$ & $\begin{array}{c}90,63 \\
5\end{array}$ & $11,72 \%$ & $14,85 \%$ \\
\hline & Skor rata-nata & $\begin{array}{c}77,57 \\
\%\end{array}$ & $\begin{array}{c}58,64 \\
\%\end{array}$ & $10,77 \%$ & $13,83 \%$ \\
\hline
\end{tabular}

Berdasarkan data angket, pada siklus I menunjukkan bahwa hanya ada 4 indikator aktivitas belajar yang memenuhi kriteria minimal yaitu indikator mengerjakan latihan soal yang diberikan guru $(82,42 \%)$, melakukan diskusi kelompok (82,62\%), menjawab pertanyaan dari guru maupun teman selama diskusi $(78,91 \%)$ dan mengerjakan kuis yang diberikan guru secara mandiri $(78,91 \%)$. Pada siklus II terdapat perubahan di mana semua indikator aktivitas belajar telah mencapai kriteria minimal yang ditentukan yaitu sebesar $75 \%$.

\section{SIMPULAN DAN SARAN}

\section{Simpulan}

Berdasarkan hasil penelitian dan pembahasan dapat disimpulkan bahwa Implementasi Model Pembelajaran Kooperatif Tipe Numbered Heads Together (NHT) dengan Media Software Jigsaw Puzzle dapat meningkatkan Aktivitas Belajar Akuntansi Siswa Kelas X Akuntansi 3 SMK Negeri 7 Yogyakarta Tahun Ajaran 2013/2014. Hal tersebut didukung dengan data penelitian yang menunjukkan adanya peningkatan pada indikator membaca materi pelajaran Akuntansi, mencatat materi pelajaran Akuntansi, melakukan diskusi kelompok, mengerjakan latihan soal yang diberikan guru, menjawab pertanyaan guru maupun teman dalam diskusi, menanggapi pendapat siswa lain, dan mengerjakan kuis yang diberikan guru secara mandiri.

Aktivitas Belajar Akuntansi meningkat pada siklus I ke II. Hal ini dibuktikan dengan adanya peningkatan persentase Aktivitas Belajar Akuntansi dari siklus I ke siklus II melalui observasi dan menyebarkan angket. Hasil observasi siklus I menunjukkan 77,23\% dan siklus II sebesar 90,077\% (Relatif). Selain itu berdasarkan angket yang didistribusikan kepada siswa dapat disimpulkan terjadi peningkatan persentase Aktivitas Belajar Akuntansi siswa sebesar 10,77\% (Absolut) 
dan 13,83\% (Relatif) dimana persentase pada siklus I sebesar $77,87 \%$ meningkat menjadi $88,64 \%$ pada siklus II.

\section{Saran}

Penelitian ini memberikan beberapa saran sebagai berikut:

a. Dalam pelaksanaan pembelajaran, guru sebaiknya menerapkan model pembelajaran yang bervariasi sehingga mampu meningkatkan aktivitas belajar siswa.

b. Diperoleh dari hasil penelitian, siswa mampu belajar mandiri tanpa terlalu bergantung pada penjelasan guru (teacher centered) selama pembelajaran, untuk pembelajaran selanjutnya guru dapat memberi kesempatan yang lebih kepada siswa agar mereka mampu belajar mandiri sehingga akan tercipta proses pembelajaran yang berpusat pada siswa (student centered).

c. Selama proses pembelajaran dengan menerapkan model pembelajaran kooperatif tipe Numbered Heads Together (NHT) dengan Media Software Jigsaw Puzzle, suasana belajar yang menyenangkan dan nyaman mampu mengoptimalkan aktivitas belajar siswa, untuk pembelajaran selanjutnya guru sebaiknya mampu menciptakan suasana belajar yang menyenangkan sehingga aktivitas belajar siswa dapat lebih optimal.

d. Siswa perlu meningkatkan aktivitas belajarnya, terutama aktivitas mencatat materi pelajaran akuntansi dan menjawab pertanyaan yang diajukan guru maupun teman selama proses pembelajaran agar mampu memahami materi pelajaran akuntansi dengan lebih maksimal.

e. Siswa dalam belajar perlu mencatat materi pelajaran tidak hanya bersumber dari buku, namun juga mencatat materi pelajaran dari penjelasan guru maupun teman, sehingga catatan materi yang dimiliki lebih lengkap dan detail.

f. Saat berdiskusi membahas materi pelajaran, jika ada pertanyaan yang diajukan guru maupun teman, bila mengetahui jawaban atas pertanyaan tersebut sebaiknya disampaikan dalam forum diskusi sehingga antarsiswa dapat saling bertukar informasi dan pengetahuan.

\section{DAFTAR PUSTAKA}

Dwi Siswoyo, dkk. (2008). Ilmu Pendidikan. Yogyakarta: UNY Press.

Martinis Yamin. (2007). Kiat Membelajarkan Siswa. Jakarta: Gaung Persada (GP) Press. 
Jurnal Pendidikan Akuntansi Indonesia, Vol. XII, No. 1, Tahun 2014

Dicky Pradana

$14-24$

M. Ngalim Purwanto. (2007). Psikologi Pendidikan. Bandung: Rosdakarya.

Oemar Hamalik. (2005). Kurikulum dan Pembelajaran. Jakarta: Bumi Aksara.
Slavin, Robert E. (2009). Cooperative Learning Teori, Riset, dan Praktik (Terjemahan). Bandung: Penerbit Nusa Media.

Sugiyono. (2007). Statistika untuk Penelitian. Bandung: CV. Alfabeta. 